\title{
Monazite Recovery by Magnetic and Gravity Separation of Medium Grade Zircon Concentrate from Senegalese Heavy Mineral Sands Deposit
}

\author{
Moumar Dieye1, Mohamadou Moustapha Thiam¹, Anthony Geneyton², Mamadou Gueye ${ }^{1}$ \\ ${ }^{1}$ Earth Science Institute, Cheikh Anta Diop Dakar University, Dakar, Senegal \\ ${ }^{2}$ Eramet Ideas, Trappes, France \\ Email: moumar.dieye@ucad.edu.sn,dieyemoumar@gmail.com
}

How to cite this paper: Dieye, M., Thiam, M.M., Geneyton, A. and Gueye, M. (2021) Monazite Recovery by Magnetic and Gravity Separation of Medium Grade Zircon Concentrate from Senegalese Heavy Mineral Sands Deposit. Journal of Minerals and Materials Characterization and Engineering, 9, 590-608.

https://doi.org/10.4236/jmmce.2021.96038

Received: October 5, 2021

Accepted: November 7, 2021

Published: November 10, 2021

Copyright $\odot 2021$ by author(s) and Scientific Research Publishing Inc. This work is licensed under the Creative Commons Attribution International License (CC BY 4.0).

http://creativecommons.org/licenses/by/4.0/

\section{(c) (i) Open Access}

\begin{abstract}
Gravity, magnetic and electrostatic separation methods allowed to obtain different titanium oxide concentrates (ilmenite, leucoxene, rutile) and different varieties of zircon concentrates (premium zircon, standard zircon, medium grade zircon standard) from Senegal's heavy mineral sands. During mining separation, monazite, which is a paramagnetic mineral, was found in a nonnegligible concentration of $0.57 \mathrm{wt} \%$ on average in the medium grade zircon standard which also contains $37.96 \mathrm{wt} \%$ zircon and $44.46 \mathrm{wt} \%$ titanium oxides. Magnetic and gravity separation tests were carried out on the Medium grade zircon standard (MGZS) to produce a monazite concentrate at Eramet Ideas laboratory. Magnetic separation at 1.5 teslas intensity resulted in the recovery of $94.8 \%$ of the monazite from the MGZS. Gravity separation also recovered $76.6 \%$ of the monazite from the MGZS. The combination of these two treatment methods can thus produce three concentrates from MGZS (a monazite concentrate, a zircon concentrate, and a titanium oxide concentrate).
\end{abstract}

\section{Keywords}

Monazite, Heavy Mineral Sands, Separation, Gravity, Magnetic

\section{Introduction}

Heavy mineral sands (HMS) have great economic interest. They are exploited to extract mainly minerals such as titanium oxides (ilmenite, rutile and leucoxene), and zircon. In some mining operation, monazite (Ce, $\mathrm{La}, \mathrm{Nd}, \mathrm{Th}) \mathrm{PO}_{4}$ is also 
recovered as a by-product. It is a mineral which therefore contains rare earth elements. In 2010, the European Commission classified rare earths as critical metals because of their importance for high-tech industry (especially green industries, e.g. lithium for batteries, rare earths for photovoltaics) coupled with the vulnerability of their exploitation (few large deposits in geopolitically unstable areas). Monazite is already recovered as a by-product in some heavy mineral sands operations, notably on beaches and alluvial deposits in India, Malaysia, Sri Lanka, Thailand and Brazil. Indian beach placers are an important source of monazite [1].

GCO mining on the great coast of Senegal focuses on titanium oxides and zirconia without concern for the presence of monazite. This study aims to quantify the amount of monazite in heavy mineral sands and to attempt recovery tests by gravity and magnetic separation.

\section{Mining Operation at GCO}

The exploitation of the deposit on the great coast of Senegal started in 2014 by Grande Côte Operations (GCO). At the end of 2017, the proven and probable reserves were re-estimated at 24.7 million tons of heavy minerals with $72 \mathrm{wt} \%$ of ilmenite, $10.7 \mathrm{wt} \%$ of zircon, $3.2 \mathrm{wt} \%$ of leucoxene and $2.5 \mathrm{wt} \%$ of rutile, i.e. 17.8 million tons of ilmenite, 2.6 million tons of zircon, 790 thousand tons of leucoxene and 617 thousand tons of rutile. The total of titanium minerals amounts to about 19 million tons. The duration of the exploitation has been re-evaluated at 35 years.

The exploitation of heavy mineral sands has many advantages compared to the exploitation of hard rock. Extraction does not require blasting. Fragmentation is absent and processing in this case requires no chemicals. It is carried out on the basis of the physical properties of the minerals such as their density, magnetism, surface electrical conductivity [2].

This mining technique at GCO consists of dredging a continuous channel, called dredge path through the dunal orebody with the dredge and the wet concentrator plant (WCP) floated on the water table. While the dredge removes the material at the front of the mine path, the tailings generated by the mineral separation process in the WCP are stacked at the back by the boom stacker and tailings lines. The tailings represent $98 \%$ of the material mined. The suction cutter dredge and the WCP progress about 15 to 30 meters per day depending on the height of the dune and the dredge pond dimensions which range between $500 \mathrm{~m}$ to $550 \mathrm{~m}$ long and between $200 \mathrm{~m}$ to $220 \mathrm{~m}$ wide [3]. The dredge pumps the slurry to the WCP, where the mineral is separated by gravity methods (spirals and cyclones). Several stages of cleaner and recleaner operation are necessary to produce heavy mineral concentrate (HMC) at $98 \%$ of heavy mineral (Figure 1). The sand tailings are pumped and deposited directly behind the WCP where the rehabilitation of the mined area proceeds.

The heavy mineral concentrate is then transported by truck to the dry process unit (MSP) where it will undergo a high intensity magnetic separation which will 


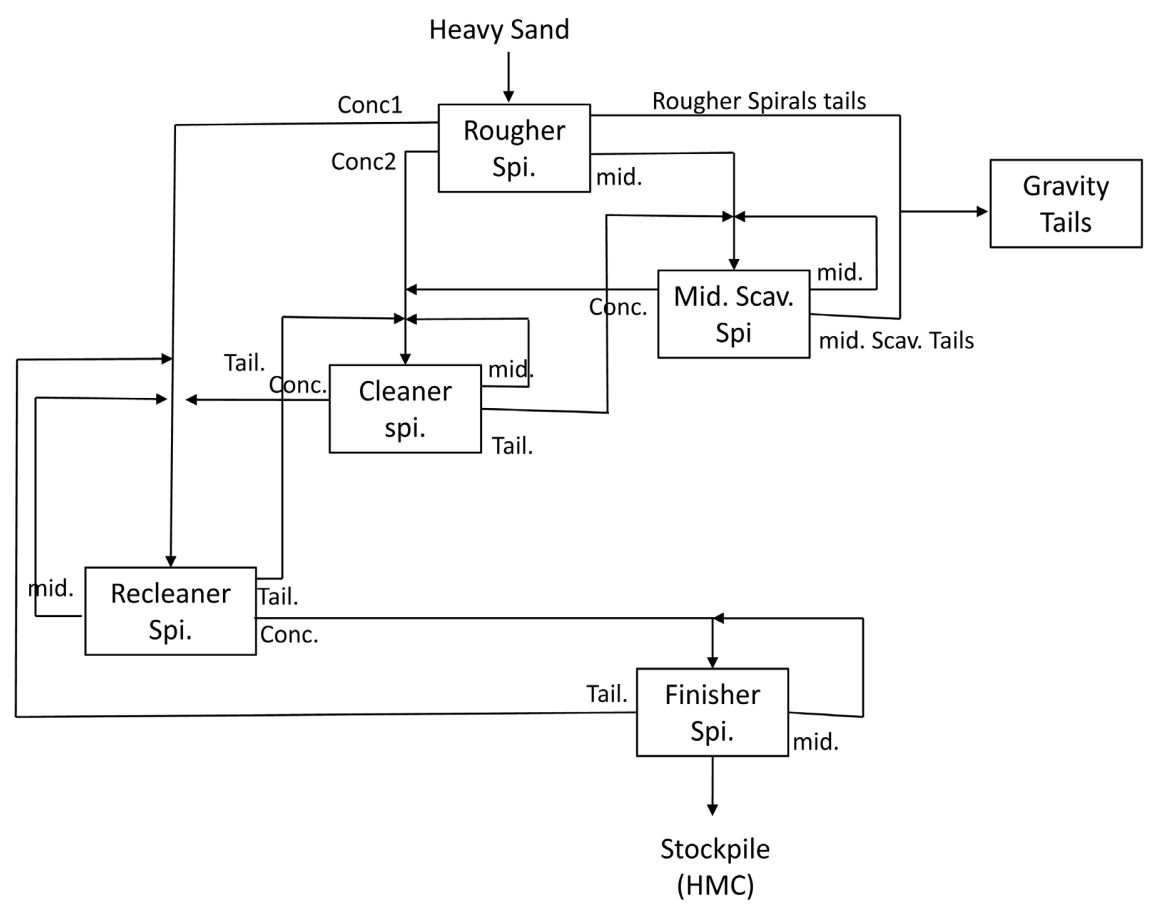

Figure 1. Heavy mineral concentration in WCP.

separate the concentrate into two products: a magnetic product (WHMag) containing ilmenite which is a ferromagnetic mineral and a non-magnetic product (WHNM) which contains most of the other heavy minerals such as zircon, rutile, leucoxene and other related minerals such as silicates and others (Figure 2). Non-magnetic products may still contain ilmenite. Indeed, altered ilmenite loses iron and becomes semi-magnetic with the possibility of being found in the nonmagnetic product concentrate [4].

These two products (magnetic and non-magnetic) will be processed in two different circuits in parallel.

The ilmenite concentrate (WHMag) will undergo a series of dry electrostatic and magnetic separations to first obtain a pure ilmenite concentrate (ilmenite 1) which is highly conductive and highly magnetic. In this process the non-conductive and non-magnetic particles are also reprocessed by electrostatic separation to produce a second ilmenite concentrate (ilmenite 2). These two concentrates produced differ in their content of titanium oxide and impurities which will define their final use. Generally, ilmenite 1 contains more than $58 \%$ titanium oxide and ilmenite 2 contains $54 \%$ titanium oxide. All of these separations generate rejects that will be recycled in the separation process.

The non-magnetic product (WHNM) is then treated to produce zircon, rutile and leucoxene concentrates. An electrostatic separation is first done. The conductive minerals are leucoxene and rutile and the non-conductive minerals are zircon.

Different categories of zirconia products will be produced using a series of magnetic and electrostatic separation (Figure 2). The categories of zirconia produced 


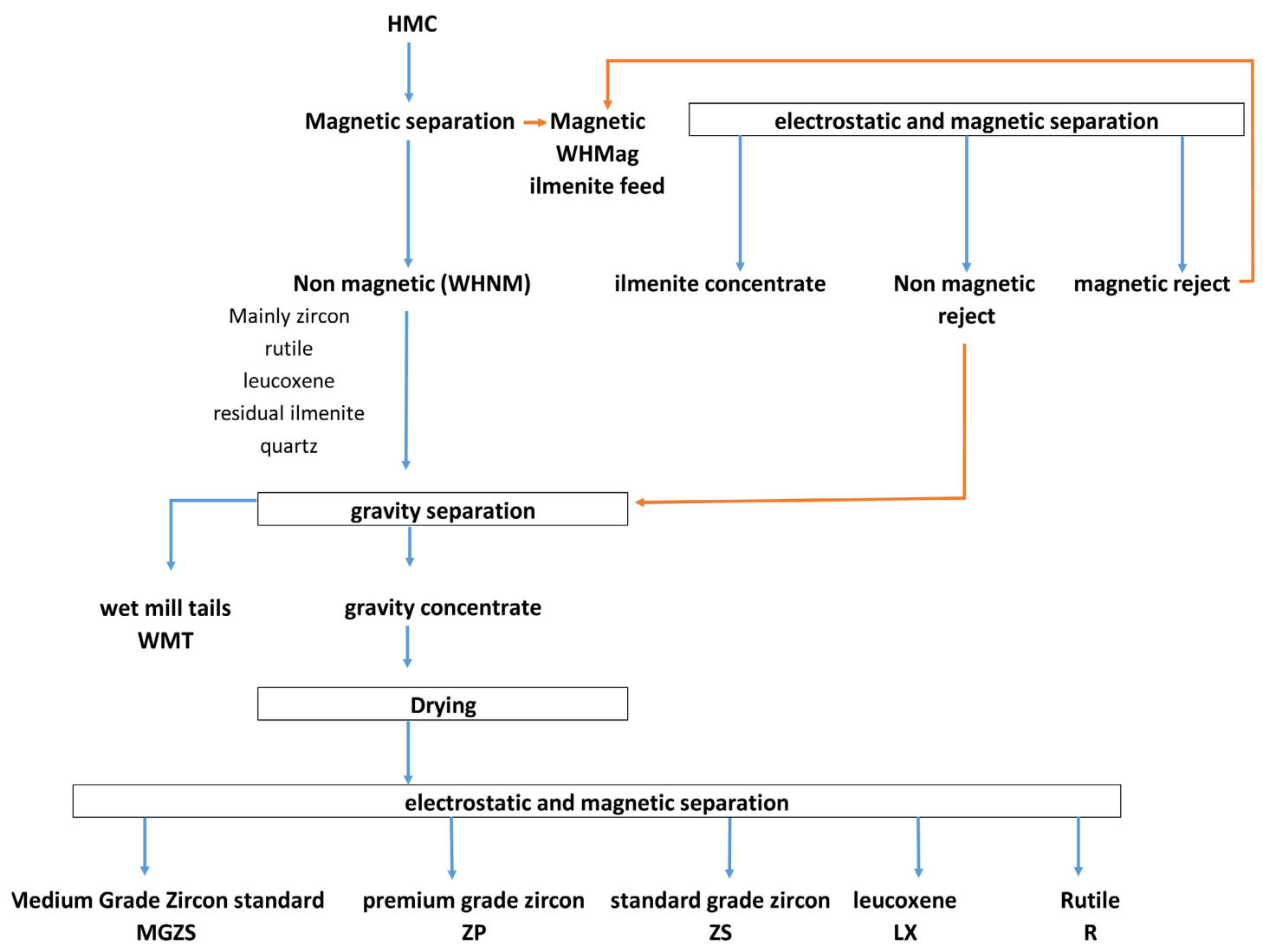

Figure 2. Heavy mineral concentration in MSP.

are: premium grade zirconia and standard grade zirconia, magnetic zirconia and standard medium grade zirconia which differ in the purity of the zirconia minerals which are often coloured by iron oxide coatings. This can greatly influence for example their magnetic properties. In other operations, a sulphuric acid etch is used to strip these surface coatings of zircon particles to make them more acceptable for use in ceramic glazes.

Conductive minerals such as leucoxene and rutile are treated by magnetic separation. Leucoxene which is an altered ilmenite is more magnetic than rutile which is non-magnetic.

\section{Materials and Methods}

\subsection{Raw Material}

In the study of the mineralogical characterization of heavy mineral concentrates [5], the results of QEMSCAN analyses showed an average concentration of 0.5 wt\% monazite in the Medium Grade Zircon Standard Concentrate (MGZS). Monazite is a non-electrically conductive and paramagnetic mineral. This explains why it is found in the MGZS product.

A $200 \mathrm{~kg}$ batch of MGZS was taken. Four samples from this batch were taken and mounted in a polished section for mineralogical analysis to confirm their monazite composition. The rest of the batch is used for recovery tests by mag- 
netic and gravity separation.

\subsection{Mineralogical Characterization}

\subsubsection{QEMSCAN}

QEMSCAN is an automated technique for the fast characterization of mineral and non-crystalline phases, on polished sections, by means of SEM (Scanning Electron Microscope)-EDS (Energy Dispersive Spectrometer). QEMSCAN analyses for this project were carried out at the ERAMET Ideas mineralogical service, using a FEI Quanta 650F SEM platform with two Bruker Xflash $30 \mathrm{~mm}$ silicon drift energy dispersive X-ray detectors. The software used included iMeasure v. 5.4 for the data acquisition and iDiscover v. 5.4 for the spectral interpretation and data processing. The "BMA (Bulk Mineral Analyses) measurement mode" was used for mineralogical characterizations of samples with collecting $\mathrm{X}$-ray data every $2.5 \mu \mathrm{m}$ across the polished sample surfaces, with X-rays acquired at 2000 total X-ray counts per spectrum. The "Field Image measurement mode" was also used to perform mineral mapping of the samples in order to observe alteration textures on a micron scale. The spectrum obtained after analysis of each point within the fields is associated with an experimental EDS spectrum using the system software. From this simulated spectrum, the software determines the relative mass concentrations of the elements present. It is thus necessary to have to fill in the database with information relating to chemical concentrations. At Eramet Ideas, this information comes from microprobe measurements. It is an innovative technology increasingly used in the rapid determination of the mineralogical compositions of sand samples. It is an innovative technology increasingly used in the rapid determination of the mineralogical compositions of sand samples [6] [7] [8] [9].

\subsubsection{Scanning Electron Microscopy}

The backscattered images of the monazite particles were taken using a JEOL JSM 6360LV scanning electron microscope equipped with a silicon drift detector analysis system at the Géosciences Environnement Toulouse (GET) laboratory in Toulouse. The compositions of the monazite grains were determined using wavelength dispersive spectrometers in the GET laboratory. The operating conditions were: an acceleration voltage of $15 \mathrm{kV}$, a beam current of $20 \mathrm{nA}$ and a beam diameter of $3 \mu \mathrm{m}$ for all the elements. Normalization was carried out using: $\mathrm{NdPO}_{4}(\mathrm{Nd}), \mathrm{SmPO}_{4}(\mathrm{Sm}), \mathrm{GdPO}_{4}(\mathrm{Gd}), \mathrm{PrPO}$ (Pr), $\mathrm{DyPO}_{4}(\mathrm{Dy})$, Woll (Ca, Si), $\mathrm{LaPO}_{4}(\mathrm{La}, \mathrm{P}), \mathrm{CePO}_{4}(\mathrm{Ce}), \mathrm{YPO}_{4}(\mathrm{Y}), \mathrm{PbJMM}(\mathrm{Pb}), \mathrm{ThO}_{2}(\mathrm{Th}), \mathrm{UO}_{2}$ (U).

\subsubsection{Inductively Plasma Optical Emission and Mass Spectrometry}

The samples were analysed at the rock and mineral analysis department of the petrographic and geochemical research center in Nancy (France). The major elements were determined by ICP-OES (Optical Emission Spectrometry) using a Thermo Fischer ICap 6500 and the trace elements by ICP-MS (Mass Spectrometry) using a Thermo Elemental X7. 


\subsection{Gravity and Magnetic Separation}

The gravity separation tests were done with a Holman Wilfley Model 800 laboratory shaker table with $75 \mathrm{~kg} /$ hour treatment capacity continuously.

The magnetic separation tests were done with a Pilot Induced Roll Magnetic Separator Mineral Technologies model RL 9011 from Eramet Ideas, which can generate a magnetic field of up to 2 teslas by adjusting an electric current.

\section{Results}

\subsection{QEMSCAN Analysis of the Medium Grade Zircon Standard Product}

The results of the QEMSCAN ${ }^{\circledR}$ analyses are shown in Table 1 . The MGZS concentrate contains on average $38 \%$ zircon, $48.8 \%$ titanium oxide, $0.57 \%$ monazite (Figure 3).

The QEMSCAN processing software was used to isolate some monazite grains shown in blue in Figure 4. The blue particles represent monazite, the purple particles are zircon and the brown particles represent titanium oxides. These monazite particles are mostly free and also show variations in color within the grains themselves, suggesting a variation in their chemical composition.

Monazite is a solid solution between 3 pure poles: pure rare earth monazite $\left(2 \mathrm{REEPO}_{4}\right)$, cheralite $\left(\mathrm{CaTh}\left(\mathrm{PO}_{4}\right)_{2}\right)$ and huttonite $2 \mathrm{Th}(\mathrm{SiO})_{4}$.

Variations in monazite composition are explained by the following substitutions [10] [11] [12] [13]:

$2 \mathrm{REE}^{3+} \leftrightarrow(\mathrm{Th}, \mathrm{U})^{4+}+\mathrm{Ca}^{2+}$ corresponding to substitution by cheralite. $\mathrm{REE}^{3+}+\mathrm{P}^{5+} \leftrightarrow(\mathrm{Th}, \mathrm{U})^{4+}+\mathrm{Si}^{4+}$ corresponding to huttonite substitution.

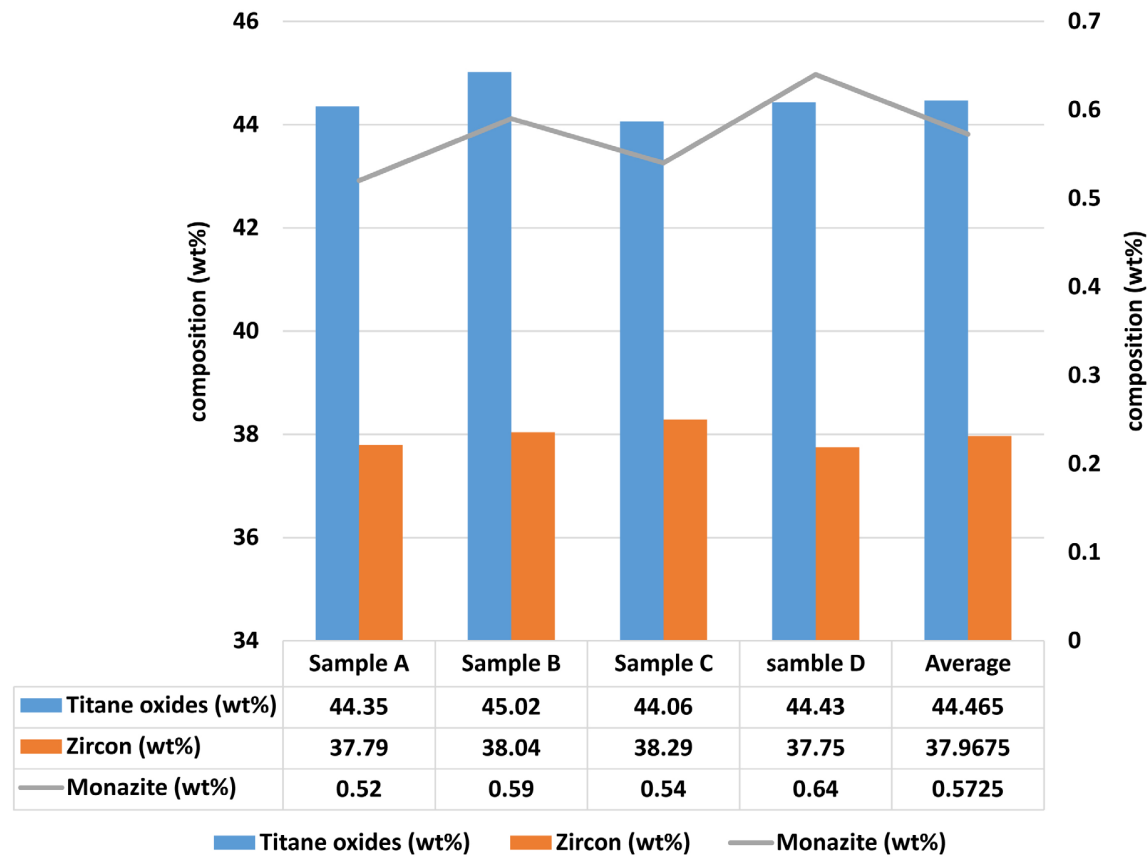

Figure 3. Minerals composition of MGZS concentrate. 


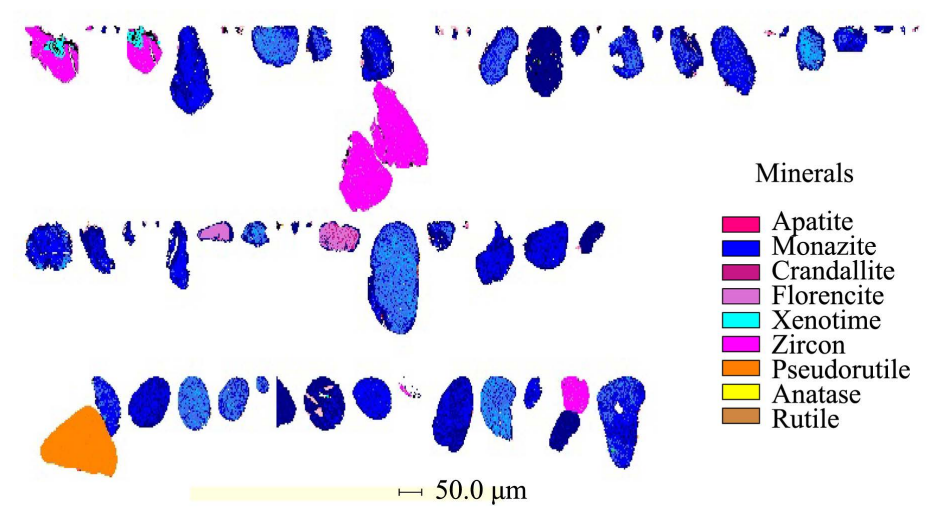

Figure 4. QEMSCAN images of monazite particles in the MGZS sample.

Table 1. MGZS minerals composition by QEMSCAN.

\begin{tabular}{|c|c|c|c|c|c|}
\hline Minerals (wt\%) & Sample A & Sample B & Sample C & Sample D & Average \\
\hline Zircon & 37.79 & 38.04 & 38.29 & 37.75 & 37.9675 \\
\hline Pseudorutile & 34.16 & 34.72 & 33.39 & 33.73 & 34 \\
\hline Rutile & 9.37 & 9.45 & 9.81 & 9.84 & 9.6175 \\
\hline Staurotide & 6.3 & 5.48 & 5.86 & 6.08 & 5.93 \\
\hline Anatase & 4.72 & 4.67 & 4.77 & 4.81 & 4.7425 \\
\hline Grenat & 1.21 & 1.2 & 1.35 & 1.32 & 1.27 \\
\hline Epidote & 1.02 & 0.97 & 1.16 & 1.06 & 1.0525 \\
\hline Tourmaline & 0.97 & 0.96 & 0.98 & 0.77 & 0.92 \\
\hline Quartz & 0.72 & 0.56 & 0.7 & 0.63 & 0.6525 \\
\hline Disthéne & 0.58 & 0.6 & 0.57 & 0.64 & 0.5975 \\
\hline Monazite & 0.52 & 0.59 & 0.54 & 0.64 & 0.5725 \\
\hline Ilménite & 0.48 & 0.54 & 0.54 & 0.53 & 0.5225 \\
\hline Kaolinite & 0.41 & 0.42 & 0.41 & 0.39 & 0.4075 \\
\hline Ilmenorutile & 0.34 & 0.31 & 0.32 & 0.33 & 0.325 \\
\hline Muscovite & 0.19 & 0.18 & 0.2 & 0.17 & 0.185 \\
\hline Priderite & 0.18 & 0.18 & 0.17 & 0.18 & 0.1775 \\
\hline Chromite & 0.18 & 0.24 & 0.19 & 0.22 & 0.2075 \\
\hline Spinelle & 0.17 & 0.18 & 0.15 & 0.24 & 0.185 \\
\hline Oxyde de Fe-Cr & 0.16 & 0.17 & 0.15 & 0.14 & 0.155 \\
\hline Amphibole & 0.13 & 0.1 & 0.11 & 0.15 & 0.1225 \\
\hline Corindon & 0.13 & 0.12 & 0.1 & 0.07 & 0.105 \\
\hline Magnetite & 0.04 & 0.05 & 0.04 & 0.04 & 0.0425 \\
\hline Titanite/Sphene & 0.02 & 0.02 & 0.02 & 0.02 & 0.02 \\
\hline Apatite & 0.02 & 0.02 & 0.02 & 0.02 & 0.02 \\
\hline Others & 0.04 & 0.06 & 0.03 & 0.04 & 0.0425 \\
\hline Total & 99.85 & 99.83 & 99.87 & 99.81 & 99.84 \\
\hline
\end{tabular}


Furthermore, monazite inclusions are also observed in zircon and rutile particles and also xenotime inclusions in zircon.

\subsection{Monazite Texture}

About 69 particles on a polished section of the MGZS sample were observed under a scanning electron microscope. If the morphology is generally random for all the grains, there are however quite significant textural variations.

The BSE (black Scattered Electron) images of monazite observed with the SEM (scanning electron microscope) make it possible to classify the monazites into 3 textural varieties with relatively homogeneous grains (Figure 5(a)), grains which have a strong zonation (5b) and very weathered grains (Figure 5(c)). These texture variations generally suggest different (magmatic, metamorphic) origins and ages [10] [14] [15] [16] (Dawood \& Abd-El Naby, 2007; Spear, 2010; Zhu \& O’Nions, 1999). The presence of fractures and more or less extensive alterations could indicate that the monazite particles have undergone alteration and transport processes from the source rock

\subsection{Monazite Recovery from MGZS}

Monazite concentration from beach placers has been studied by various authors [17] [18] [19] [20]. The separation methods used are the same as for the concentration of zircon and titanium oxides, i.e. magnetic and gravitational separation,
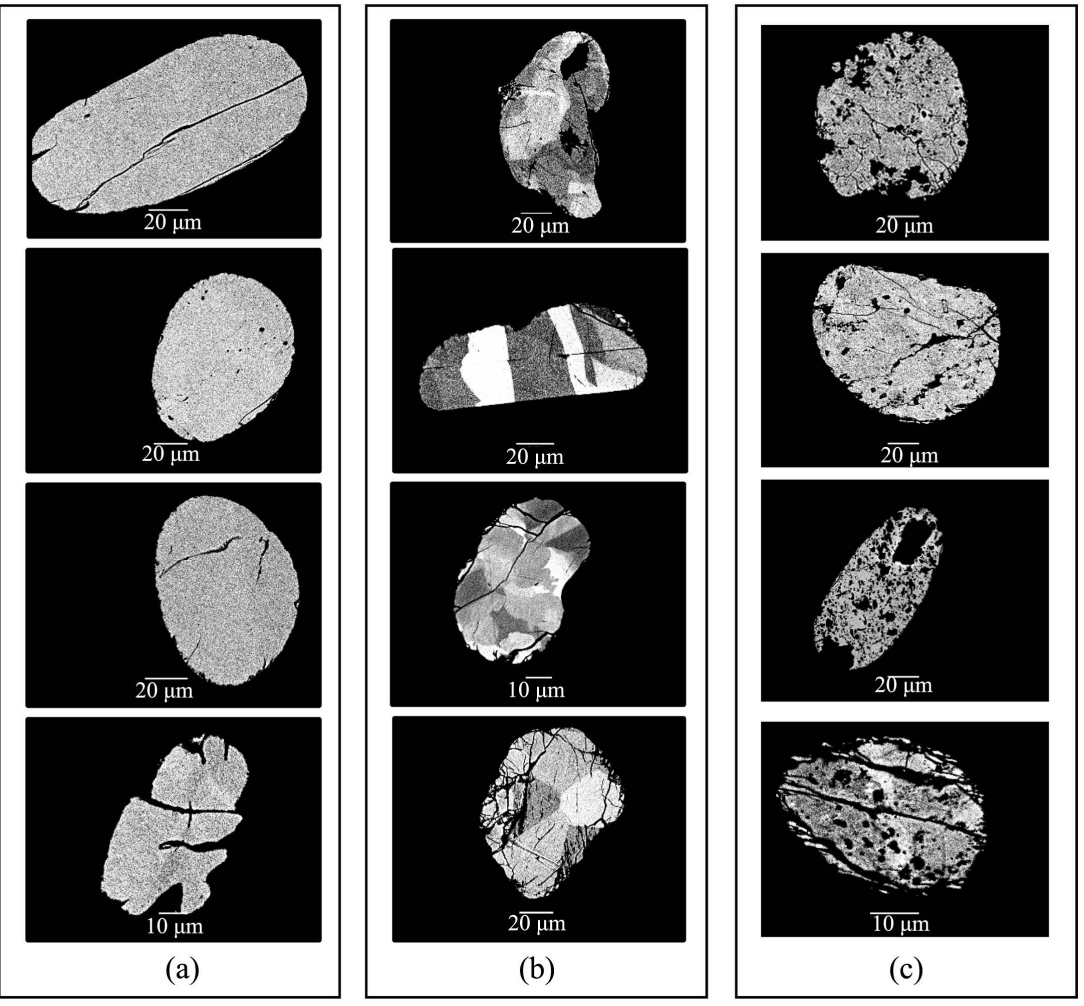

Figure 5. BSE images of monazite particles: (a) homogeneous particles; (b) zoned particles; (c) very altered particles. 
sometimes combined with electrostatic separation. The chemical composition of the feed guides the choice of separation methods. Figure 6 shows the density differences between the different heavy minerals in the sands of Senegal revealed by the QEMSCAN software. Titanium oxides density is 4.5 , zircon and monazite are 4.5. Concentration by gravity separation is therefore possible.

Table 2 shows the magnetic susceptibility differences between the different minerals in the sands. Zircon has a low magnetic susceptibility, titanium oxides have a high magnetic susceptibility and monazite has a medium magnetic susceptibility. The magnetic susceptibility values of these different minerals can

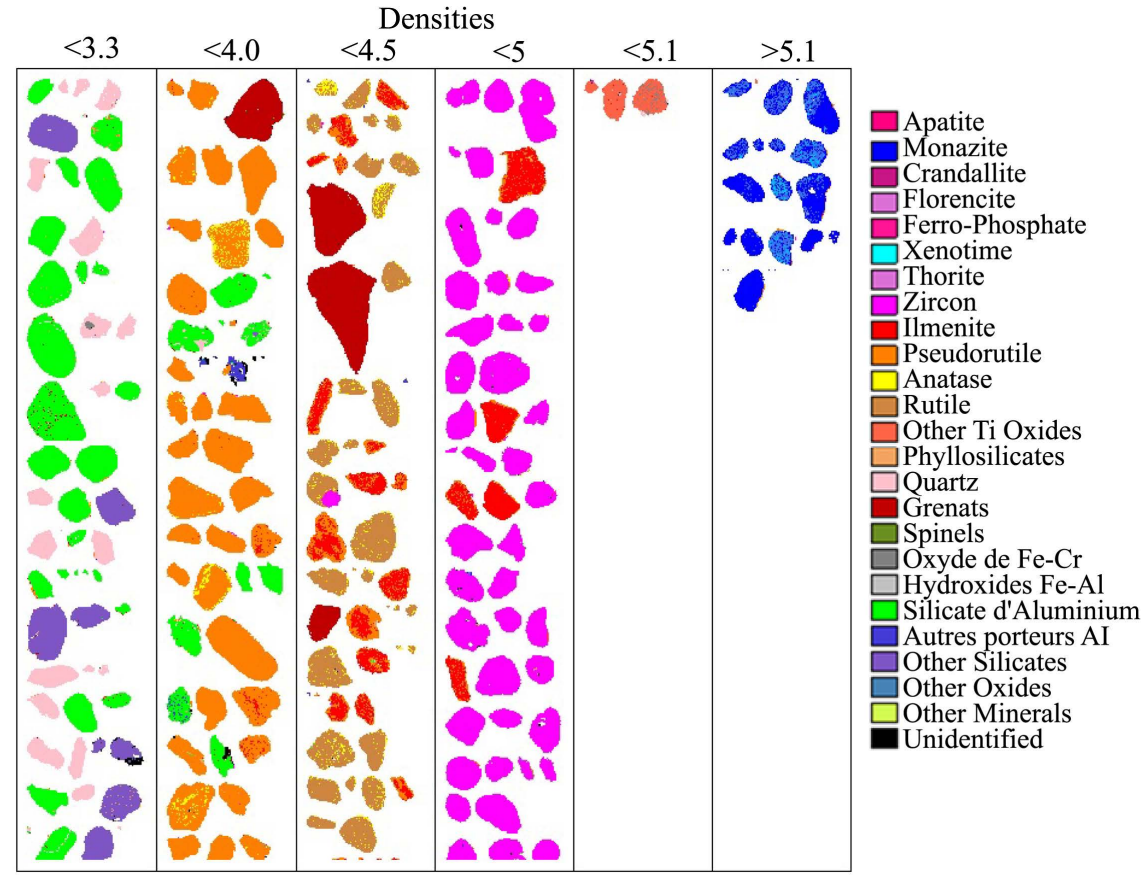

Figure 6. Densities distribution of minerals in MGZS.

Table 2. Physical properties of heavy mineral sand.

\begin{tabular}{ccccc}
\hline Mineral & $\begin{array}{c}\text { Magnetic } \\
\text { susceptibility }\end{array}$ & $\begin{array}{c}\text { Electrical } \\
\text { conductivity }\end{array}$ & $\begin{array}{c}\text { SG } \\
\left(\mathrm{g} / \mathrm{cm}^{3}\right)\end{array}$ & Chemical formula \\
\hline Ilmenite & high & High & $4.5-5$ & $\mathrm{Fe} \cdot \mathrm{TiO}_{3}$ \\
Rutile & low & High & $4.2-4.3$ & $\mathrm{TiO}_{2}$ \\
Zircon & low & Low & 4.7 & $\mathrm{ZrSiO}_{4}$ \\
Leucoxene & Semi & High & $3.5-4.1$ & $\mathrm{Fe} \cdot \mathrm{TiO}_{3} \cdot \mathrm{TiO}_{2}$ \\
Monazite & Semi & Low & $4.9-5.3$ & $\left(\mathrm{Ce}, \mathrm{La}, \mathrm{Th}_{2} \mathrm{Nd}_{2} \mathrm{Y}_{2} \mathrm{PO}_{4}\right.$ \\
Staurolite & Semi & Low & $3.6-3.8$ & $\mathrm{Fe} 2 \mathrm{Al}_{9} \mathrm{Si}_{4} \mathrm{O}_{22} \cdot(\mathrm{OH})_{2}$ \\
Kyanite & Low & Low & $3.6-3.7$ & $\mathrm{Al}_{2} \mathrm{SiO}_{5}$ \\
Garnet & Semi & Low & $3.4-4.2$ & $\left(\mathrm{Fe}, \mathrm{Mn}, \mathrm{Ca}_{3} \cdot \mathrm{Al}_{2}\left(\mathrm{SiO}_{4}\right)_{3}\right.$ \\
Quartz & low & low & 2.7 & $\mathrm{SiO}_{2}$ \\
\hline
\end{tabular}


nevertheless vary according to the modification of their composition during the alteration process from the source rock. Thus a magnetic separation between these different products is possible.

According the different separation methods used for monazite recovery, gravity and magnetic separation were chosen to do tests on the MGZS concentrate produced by GCO at Senegalese deposit.

\subsection{Magnetic Concentration}

The magnetic separation tests were done according to various indications in the literature. Monazite is a paramagnetic mineral that can react in a magnetic field at an intensity of about 1.5 teslas. In order to achieve maximum recovery, the magnetic separation treatment scheme in Figure 7 was adopted. All magnetic separations were performed at 1.5 teslas intensity.

A primary magnetic separation produced 3 products: Magnetic, mids and non-magnetic. The non-magnetic product still undergoes magnetic separation in order to recover the magnetic particles in sterile product. A tertiary magnetic separation is done on the magnetic and mixed concentrates. The non-magnetic resulting from this separation will undergo further magnetic separation and release final steriles. Finally the magnetic and mids concentrates are combined to form the final magnetic concentrate.

At end, three products are obtained from the feed:

- A magnetic concentrate C

- A sterile S1

- A sterile S2

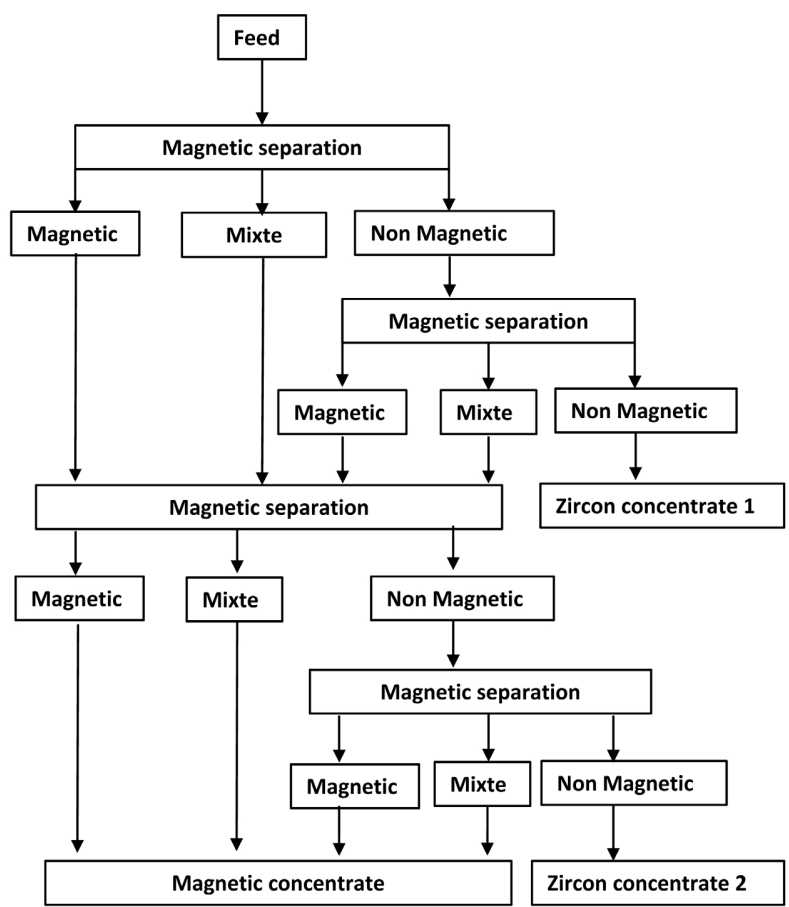

Figure 7. Magnetic separation flowsheet. 
Table 3 shows the analysis results by ICP-OES and ICP-MS of the samples from the magnetic separation. Product $\mathrm{C}$ is the magnetic separation concentrate and products $\mathrm{S} 1$ and $\mathrm{S} 2$ are the sterile.

These results show a high concentration of rare earths and titanium oxides in the magnetic separation concentrate. Zircon is more concentrated in sterile S1 and S2. The magnetic separation appears to have concentrated the rare earth minerals and titanium oxides which are more magnetic than zircon (Figure 8).

\subsection{Gravity Concentration}

Mineral gravity concentration depends on the specific densities of the different minerals present.

The optimization of monazite recovery by gravity concentration with shaking table required numerous tests. Indeed, the adjustment of the different operation parameters (table incline, solid feed flow, water flow) can only be optimized through tests and a visual rendering of separation between dense and light minerals. Furthermore, the efficiency of a density separation depends greatly on the difference in density between the minerals to be separated. In general, this difference should be at least $1 \mathrm{~g} / \mathrm{cm}^{3}$. The small difference in density between the heavy minerals present here (monazite, zircon; titanium oxides) leads us to consider an optimization of the shaking table settings (increase in slope, washing water etc.).

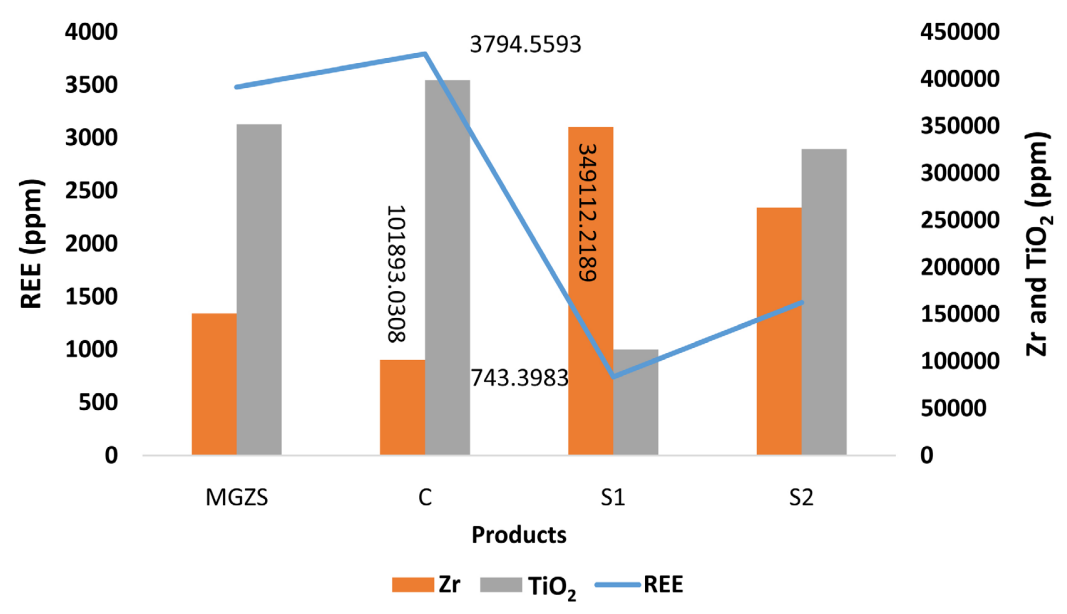

Figure 8. $\mathrm{REE}, \mathrm{Zr}$ and $\mathrm{TiO}_{2}$ concentration in samples after magnetic separation.

Table 3. Result of chemical analyzes of magnetic separation samples.

\begin{tabular}{cccccccccccccc}
\hline & $\mathrm{SiO}_{2}$ & $\mathrm{Al}_{2} \mathrm{O}_{3}$ & $\mathrm{Fe}_{2} \mathrm{O}_{3}$ & $\mathrm{MnO}$ & $\mathrm{MgO}$ & $\mathrm{CaO}$ & $\mathrm{Na}_{2} \mathrm{O}$ & $\mathrm{K}_{2} \mathrm{O}$ & $\mathrm{TiO}_{2}$ & $\mathrm{P}_{2} \mathrm{O}_{5}$ & $\mathrm{REE}$ & $\mathrm{Zr}$ & $\mathrm{Others}$ \\
\cline { 2 - 12 } & $\%$ & $\%$ & $\%$ & $\%$ & $\%$ & $\%$ & $\%$ & $\%$ & $\%$ & $\%$ & $\mathrm{ppm}$ & $\mathrm{ppm}$ & $\mathrm{ppm}$ \\
\hline $\mathrm{MGZS}$ & 15.54 & 6.07 & 14.92 & 0.37 & 0.35 & 0.64 & 0.03 & $<$ L.D. & 35.21 & 0.32 & 3479.66 & 151,030 & $10,858.9$ \\
$\mathrm{C}$ & 12.31 & 6.98 & 18.15 & 0.47 & 0.46 & 0.74 & 0.04 & 0.04 & 39.88 & 0.36 & 3794.56 & 101,893 & $10,963.5$ \\
$\mathrm{~S} 1$ & 29.08 & 1.73 & 0.16 & <L.D. & $<$ L.D. & 0.06 & $<$ L.D. & 0.03 & 11.26 & 0.13 & 743.40 & 349,112 & 9838.0 \\
$\mathrm{~S} 2$ & 21.21 & 1.71 & 0.59 & <L.D. & <L.D. & 0.12 & $<$ L.D. & 0.05 & 32.55 & 0.19 & 1446.05 & 263,609 & $10,121.3$ \\
\hline
\end{tabular}


The multiple tests carried out have made it possible to determine the settings shown in Figure 9.

The following parameters allowed a good separation based on visual observation. Indeed zircon and monazite have a light shade compared to titanium oxides and have a fluorescence under UV lamp:

- Solid flow rate: $23.6 \mathrm{~kg} / \mathrm{h}$

- Liquid supply flow rate: $2.89 \mathrm{~L} / \mathrm{min}$

- Liquid flow rate of the table: $14.91 \mathrm{~L} / \mathrm{min}$

- Shaking frequency: $300 \mathrm{~Hz}$

- Longitudinal tilt of the table: 3 degrees

- Lateral table tilt: 7.8 degrees

Thus 4 products are recovered:

- A concentrate of clear products (C)

- A concentrate of Mixed 1 (M1)

- A concentrate of Mixed 2 (M2)

- A sterile (S)

Table 4 shows the analysis results by ICP-OES and ICP-MS of the samples from the gravimetric separation. Product $\mathrm{C}$ is the shaking table concentrate.

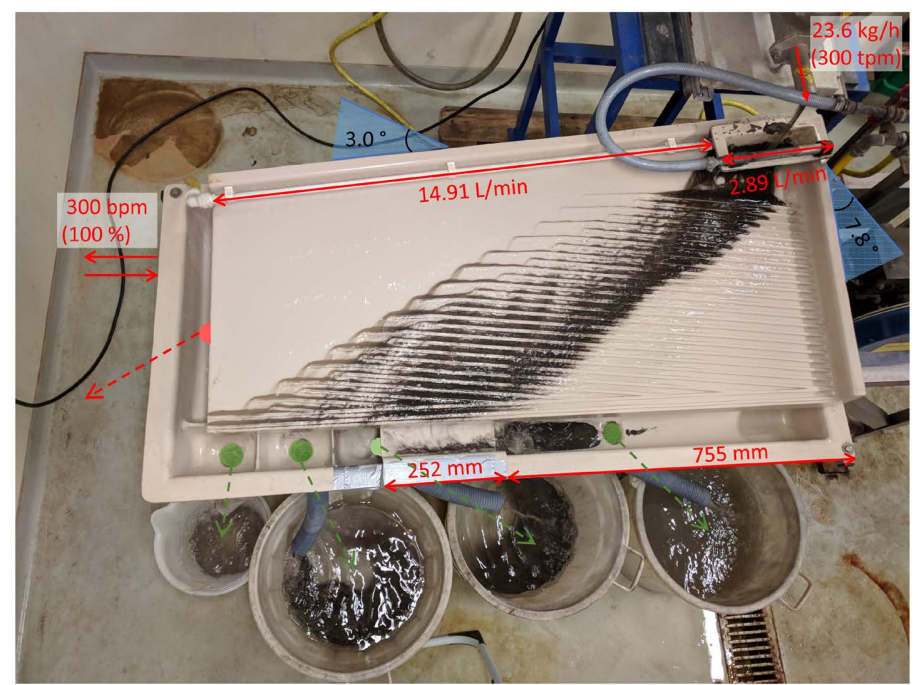

Figure 9. Operating conditions for gravimetric separation by shaking table.

Table 4. Overall result of gravimetric separation sample analyses.

\begin{tabular}{ccccccccccccccc}
\hline & $\mathrm{SiO}_{2}$ & $\mathrm{Al}_{2} \mathrm{O}_{3}$ & $\mathrm{Fe}_{2} \mathrm{O}_{3}$ & $\mathrm{MnO}$ & $\mathrm{MgO}$ & $\mathrm{CaO}$ & $\mathrm{Na}_{2} \mathrm{O}$ & $\mathrm{K}_{2} \mathrm{O}$ & $\mathrm{TiO}_{2}$ & $\mathrm{P}_{2} \mathrm{O}_{5}$ & $\mathrm{REE}$ & $\mathrm{Zr}$ & $\mathrm{Others}$ \\
\cline { 2 - 12 } & $\%$ & $\%$ & $\%$ & $\%$ & $\%$ & $\%$ & $\%$ & $\%$ & $\%$ & $\%$ & $\mathrm{ppm}$ & $\mathrm{ppm}$ & $\mathrm{ppm}$ \\
\hline $\mathrm{MGZS}$ & 15.54 & 6.07 & 14.92 & 0.37 & 0.35 & 0.64 & 0.03 & $<$ L.D. & 35.21 & 0.32 & 3479.7 & 151,030 & 10,859 \\
$\mathrm{C}$ & 26.66 & 0.62 & 2.74 & 0.03 & $<$ L.D. & 0.124 & $<$ L.D. & $<$ L.D. & 6.042 & 1.72 & 26202 & 356,203 & 17,627 \\
$\mathrm{M} 1$ & 19.02 & 1.99 & 11.14 & 0.28 & 0.15 & 0.20 & $<$ L.D. & $<$ L.D. & 25.39 & 0.34 & 3639.9 & 230,553 & 11,909 \\
$\mathrm{M} 2$ & 16.72 & 3.32 & 12.58 & 0.32 & 0.24 & 0.33 & $<$ L.D. & $<$ L.D. & 31.23 & 0.28 & 2564.5 & 200,992 & 11,917 \\
$\mathrm{~S}$ & 13.15 & 8.65 & 17.33 & 0.44 & 0.51 & 0.90 & 0.045 & 0.037 & 41.29 & 0.22 & 1307.6 & 79,162 & 8917.8 \\
\hline
\end{tabular}


Products M1 and M2 are mixed and Product S is the waste rock from this concentration operation.

These results show a high concentration of rare earths and zirconium in concentrate $\mathrm{C}$ (Figure 10). The sterile product $S$ is low in these elements. Products $\mathrm{M} 1$ and M2 show higher concentrations of zircon and less rare earth minerals.

\section{Discussions}

The results of the analyses below give the compositions in rare earths and also in zirconium. From these analyses it is possible to reconstitute the monazite and zircon content of the different products obtained. Indeed, the microprobe analyses carried out by the GET laboratory in Toulouse have shown that the monazites in the MGZS product were made up of an average of $58.14 \%$ rare earths. Furthermore, the zircon of formula $\mathrm{ZrSiO}_{4}$ is $43.14 \%$ zirconium (Zr). QEMSCAN ${ }^{\circ}$ analyses of this product showed that monazite is free and virtually the only rare earth bearing mineral.

It is therefore possible to reconstitute the monazite and zirconium contents of the different products from the rare earth and zirconium analyses by applying the following formulas:

$$
\begin{aligned}
& \text { Monazite Grade: } \frac{\text { total REE }}{\mathrm{REE} \text { in monazite }} \text {; } \\
& \text { Zircon Grade: } \frac{\text { total } \mathrm{Zr}}{\mathrm{Zr} \text { in zircon }} .
\end{aligned}
$$

Following Table 5 shows the concentration of monazite and zircon after magnetic separation in the different products as well as the recoveries by weight of concentrate and mineral.

The results in this table show that almost $95 \%$ of the monazites were found in the concentrate $(\mathrm{C})$, which constitutes a very good recovery rate. Magnetic separation at an intensity of 1.5 teslas therefore made it possible to concentrate them. The concentrate (C) then has a content of $0.65 \%$ monazite and $23.62 \%$ zircon. In addition, product $\mathrm{S} 1$ has a high concentration of zircon at a content of $80.93 \%$.

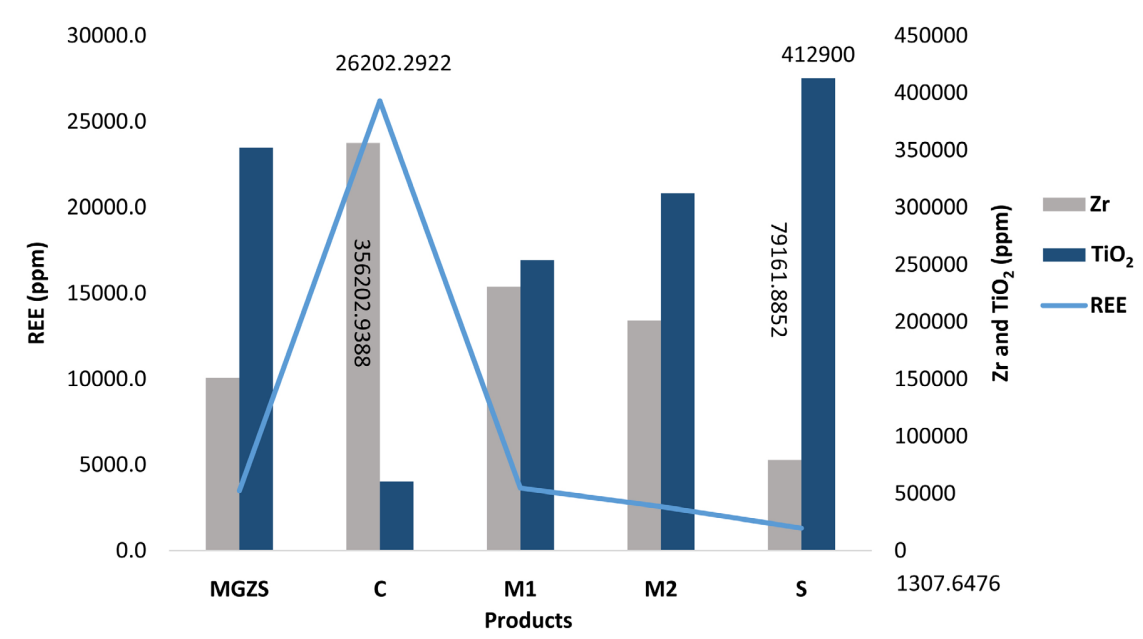

Figure 10. $\mathrm{REE}, \mathrm{Zr}$ and $\mathrm{TiO}_{2}$ concentration in samples after gravity separation. 
Table 5. Monazite and zircon distribution after magnetic separation.

\begin{tabular}{ccccccc}
\hline & $\begin{array}{c}\text { Mass } \\
(\mathrm{g})\end{array}$ & $\begin{array}{c}\text { Mass } \\
(\%)\end{array}$ & $\begin{array}{c}\text { Monazite } \\
(\mathrm{wt} \%)\end{array}$ & $\begin{array}{c}\text { Zircon } \\
(\mathrm{wt} \%)\end{array}$ & $\begin{array}{c}\text { Monazite } \\
\text { recovery (\%) }\end{array}$ & $\begin{array}{c}\text { zircon } \\
\text { recovery (\%) }\end{array}$ \\
\hline C & 802 & $80.20 \%$ & $0.65 \%$ & $23.62 \%$ & $94.80 \%$ & $55.05 \%$ \\
S1 & 170 & $17.00 \%$ & $0.13 \%$ & $80.93 \%$ & $3.94 \%$ & $39.98 \%$ \\
S2 & 28 & $2.80 \%$ & $0.25 \%$ & $61.11 \%$ & $1.26 \%$ & $4.97 \%$ \\
$\begin{array}{c}\text { MGZS } \\
\text { reconstituted }\end{array}$ & 1000 & $100 \%$ & $0.55 \%$ & $34.41 \%$ & $100 \%$ & $100 \%$ \\
\hline
\end{tabular}

Table 6 shows the distribution of monazite and zircon after gravity separation in the different products as well as the recovery by weight and mineral.

The results in this table show that about $40.13 \%$ of the monazites in the MGZS were found in the concentrate (C). The monazite in this product has then a content of $4.51 \%$ with $82.57 \%$ zircon. In addition, mixed product 1 and mixed product 2 have respectively contents of $0.63 \%$ and $0.44 \%$ monazite with $53.44 \%$ and $46.59 \%$ zircon.

From the results of the shaking table separation it is interesting to make combinations between the different products to follow the evolution of the recovery and the contents of monazite and zircons according to the weights of the different products.

Following Table 7 and Table 8 give the contents and recovery of the different shaking table products combined.

Figure 11 and Figure 12 show the evolution of monazite and zircon grades and recoveries as a function of weight yields. The recoveries of monazite and zircon evolve inversely to their grades. It is important to note that the more monazite is recovered, the lower the grade of the concentrate obtained.

Taking concentrate $\mathrm{C}$ as the final product, the monazite recovery is $40.1 \%$ with a content of $4.51 \%$; the zircon recovery is $11.9 \%$ with a content of $82.57 \%$. Taking $\mathrm{C}+\mathrm{M} 1+\mathrm{M} 2$ as the final concentrate, monazite recovery would be $76.62 \%$ with a grade of $0.62 \%$; zircon recovery is $69.1 \%$ with a grade of $52.76 \%$. A magnetic separation of the table top concentrate by shaking allows an optimal recovery of monazite with the possibility to obtain a very high grade zircon concentrate.

It is important to note that these processing operations are carried out in a single step. It is perfectly possible to plan two to three additional treatment stages by recycling the waste rock in order to maximise the recovery of monazite and zircon.

A combination of shake table separation and then magnetic separation can be established through the treatment scheme in Figure 13.

The sterile material from the first shaking table operation is therefore enriched in titanium oxides with a certain amount of zircon and monazite. A magnetic separation of this product at a medium intensity can be envisaged to obtain a zircon and monazite concentrate on the one hand and a titanium oxide concentrate 


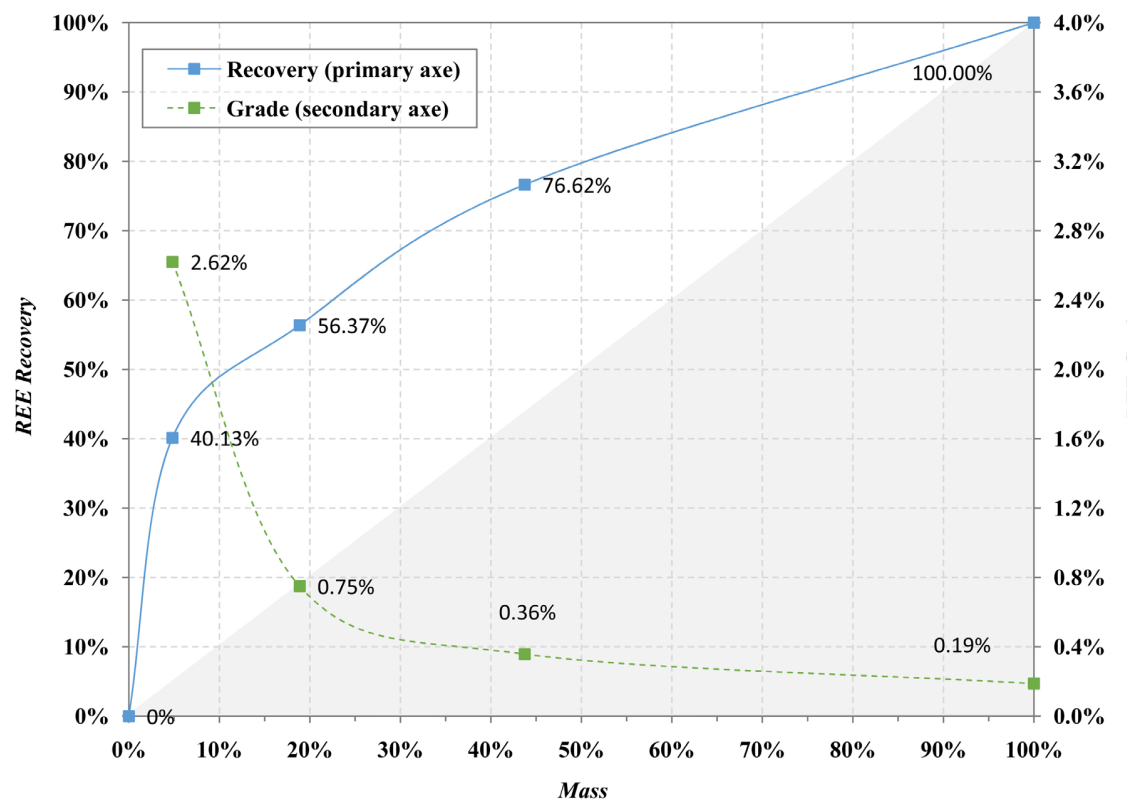

Figure 11. Evolution of monazite content and recovery as a function of weight yield.

Table 6. Monazite and zircon distribution after gravity separation.

\begin{tabular}{cccccc}
\hline & $\begin{array}{c}\text { Mass } \\
(\%)\end{array}$ & $\begin{array}{c}\text { Monazite } \\
(\%)\end{array}$ & $\begin{array}{c}\text { Zircon } \\
(\%)\end{array}$ & $\begin{array}{c}\text { monazite } \\
\text { recovery (\%) }\end{array}$ & $\begin{array}{c}\text { zircon } \\
\text { recovery (\%) }\end{array}$ \\
\hline C & $4.82 \%$ & $4.51 \%$ & $82.57 \%$ & $40.13 \%$ & $11.92 \%$ \\
M1 & $14.05 \%$ & $0.63 \%$ & $53.44 \%$ & $16.24 \%$ & $22.48 \%$ \\
M2 & $24.85 \%$ & $0.44 \%$ & $46.59 \%$ & $20.25 \%$ & $34.68 \%$ \\
S & $56.28 \%$ & $0.22 \%$ & $18.35 \%$ & $23.38 \%$ & $30.92 \%$ \\
MGZS & $100 \%$ & $0.54 \%$ & $33.40 \%$ & $100 \%$ & $100 \%$ \\
reconstituted & & & & & \\
\hline
\end{tabular}

Table 7. Monazite distribution in the different samples combined.

\begin{tabular}{cccc}
\hline Monazite & Mass (\%) & Grade (\%) & Recovery (\%) \\
\hline C & $4.82 \%$ & $4.51 \%$ & $40.1 \%$ \\
C + M1 & $18.87 \%$ & $1.29 \%$ & $56.4 \%$ \\
C + M1 + M2 & $43.72 \%$ & $0.62 \%$ & $76.6 \%$ \\
C + M1 + M2 + S & $100.00 \%$ & $0.32 \%$ & $100 \%$ \\
\hline
\end{tabular}

Table 8. Zircon distribution in the different samples combined.

\begin{tabular}{cccc}
\hline Zircon & Mass (\%) & Grade (\%) & Recovery (\%) \\
\hline C & $4.82 \%$ & $82.57 \%$ & $11.9 \%$ \\
C + M1 & $18.87 \%$ & $60.88 \%$ & $34.4 \%$ \\
C + M1 + M2 & $43.72 \%$ & $52.76 \%$ & $69.1 \%$ \\
C + M1 + M2 + S & $100.00 \%$ & $33.40 \%$ & $100 \%$ \\
\hline
\end{tabular}




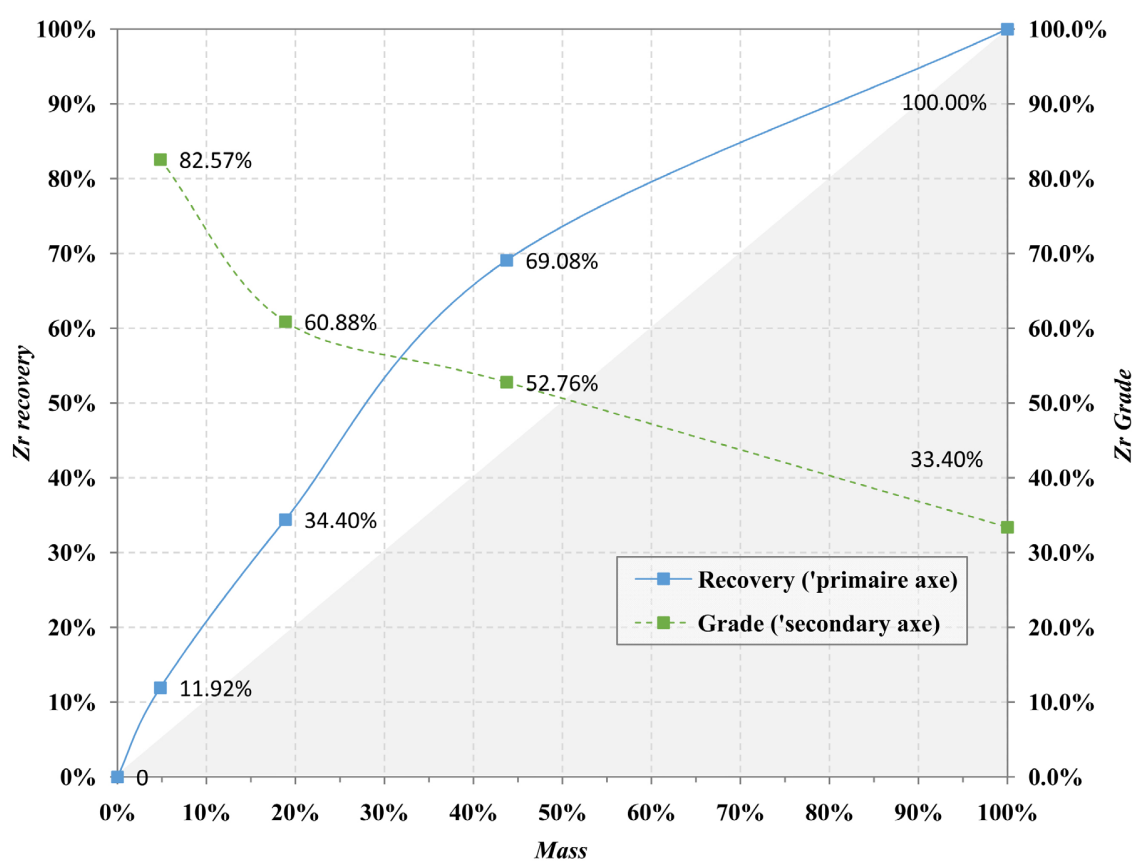

Figure 12. Evolution of zircon content and recovery as a function of weight yield.

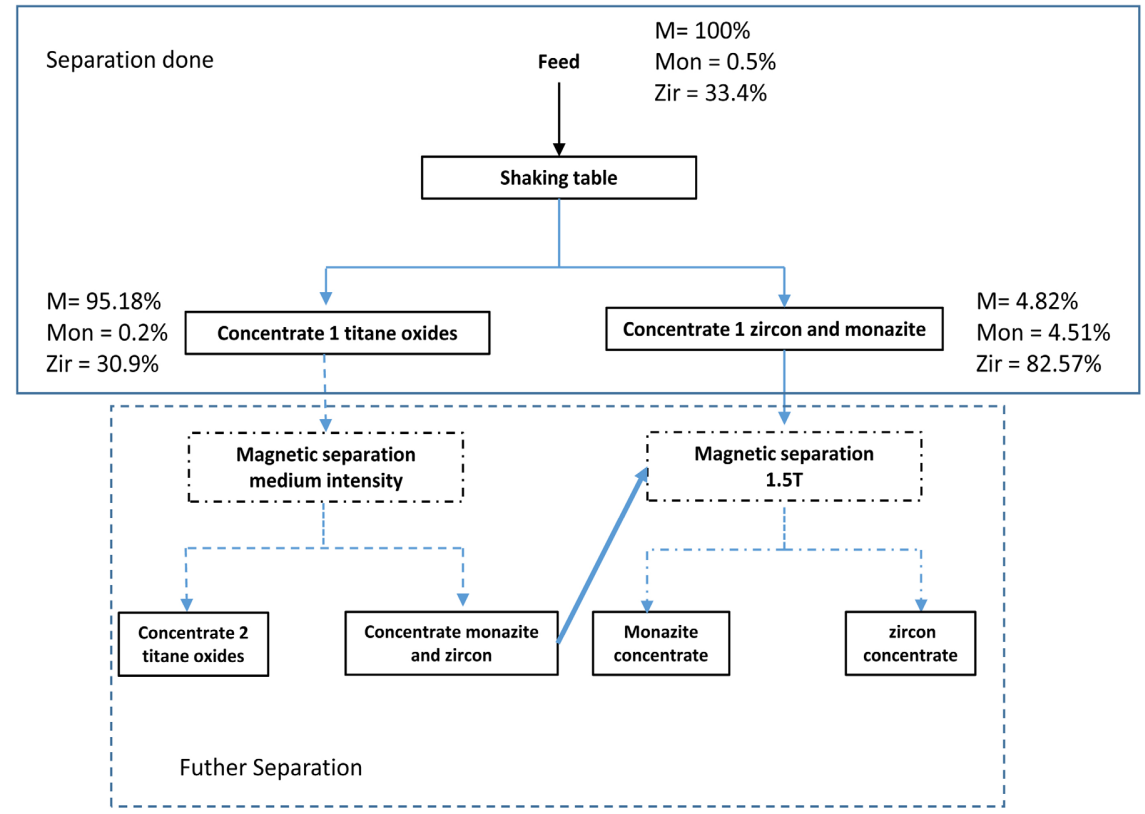

Figure 13. Global flowsheet for processing optimization of the MGZS product.

on the other hand. Monazite and zircon can then be separated by high intensity magnetic separation. The diagram in Figure 13 therefore proposes a two-stage treatment in parallel allowing the recovery of monazite and zircon to be optimised with the possibility of obtaining a titanium oxide concentrate.

\section{Conclusions}

QEMSCAN and ICPMS analysis confirmed the monazite concentration in Me- 
dium Grade Zircon Standard. Tests to recover monazite from the Medium Grade Zircon Standard concentrate gave interesting results. Magnetic and gravity separation was proved to be effective. It was possible to produce a monazite + titanium oxides concentrate and a zircon concentrate with magnetic separation. In addition, it was possible to produce a zircon + monazite concentrate and a titanium oxide concentrate.

The combination of magnetic and gravity separation can be considered to produce a monazite, zircon and titanium oxide concentrate from MGZS. The MGZS concentrate is today sold as a low zircon concentrate. Its valorization can be of definite economic interest. With a production of 28291 tonnes of MGZS produced in 2018 [21], GCO can consider reprocessing this product in order to better valorise it and increase its profit. However, an economic assessment taking into account the treatment costs must be considered.

\section{Acknowledgements}

We graciously thank the Institute for Research and Development (IRD) for funding a large part of the work, as well as the French Embassy, which funded stays in France through a grant. We appreciate the strong participation of the company Grande Côte Opérations (GCO) who accepted this study and provided the necessary information and equipment. We would like to thank the Petro-structural laboratory of the Dakar Institute of Earth Sciences for making and preparing the samples. Finally, we would like to thank the GET laboratory (Georessource environment Toulouse) and Eramet Ideas for carrying out all of the analyses and their expertise in this study.

\section{Conflicts of Interest}

The authors declare no conflicts of interest regarding the publication of this paper.

\section{References}

[1] Van Gosen, B.S., Fey, D.L., Salah, A.K., Verplank, P.L. and Hoefen, T.M. (2014) Deposit Model for Heavy-Mineral Sands in Coastal Environments: Scientific Investigations Report 2010-5070-L. U.S. Geological Survey, Reston, VA, 51 p. https://doi.org/10.3133/sir20105070L

[2] Chakhmouradian, A.R and Wall, F. (2012) Rare Earth Elements: Minerals, Mines, Magnets (and More). Elements, 8, 333-340. https://doi.org/10.2113/gselements.8.5.333

[3] Seck, M., Faye, S., Robertson, M. and Rose, M. (2018) Recycling Tailings Seepage Water for Diogo Heavy Minerals Mine Sustainability (Northern Senegal). Journal of Water Resource and Protection, 10, 121-144. https://doi.org/10.4236/jwarp.2018.101008

[4] Delaporte, A., Blancher, S., Goncalves, P. and Wallmach, T. (2018) Physical Property Changes of Fe-Ti Oxides along Their Alteration: A Geometallurgical Study to Improve the Yield of a Mineralurgical Plant. IMPC Conference, Moscow, 17-21 September 2018, 1-22. 
[5] Dieye, M., Van Lichtervelde, M., Ndiaye, A.A., Gueye, M. and Blancher, S.B. (2020) Mineralogical Characterization of Heavy Mineral Concentrates from Senegalese Great Cost by Using QEMSCAN and SEM. International Journal of Geosciences, 11, 800817. https://doi.org/10.4236/ijg.2020.1112041

[6] Edahbi, M., Benzazoua, M., Plante, M., Doire, S. and Kormos, L. (2018) Mineralogical Characterization Using QEMSCAN ${ }^{\circledR}$ and Leaching Potential Study of REE within Silicate Ores: A Case Study of the Matamec Project, Québec, Canada. Journal of Geochemical Exploration, 185, 64-73. https://doi.org/10.1016/j.gexplo.2017.11.007

[7] Guanira, K., Valente, T., Rios, C., Castellanos, O., Salazar, L., Lattanzi, D. and Jaime, P. (2020) Methodological Approach for Mineralogical Characterization of Tailings from a $\mathrm{Cu}(\mathrm{Au}, \mathrm{Ag})$ Skarn Type Deposit Using QEMSCAN (Quantitative Evaluation of Minerals by Scanning Electron Microscopy). Journal of Geochemical Exploration, 209, Article ID: 106439. https://doi.org/10.1016/j.gexplo.2019.106439

[8] Mackay, D., Simandl, G., Ma, W., Redfearn, M. and Gravel, J. (2016) Indicator Mineral-Based Exploration for Carbonatites and Related Specialty Metal Deposits-A QEMSCAN $^{\circledast}$ Orientation Survey, British Columbia, Canada. Journal of Geochemical Exploration, 165, 159-173. https://doi.org/10.1016/j.gexplo.2016.03.005

[9] Smyte, D., Lombard, A. and Coetzee, L. (2013) Rare Earth Element Deportment Studies Utilising QEMSCAN Technology. Minerals Engineering, 52, 52-61.

https://doi.org/10.1016/j.mineng.2013.03.010

[10] Dawood, Y.H. and Abd-El Naby, H.H. (2007) Mineral Chemistry of Monazite from the Black Sand Deposits, northern Sinaï, Egypt: A Provenance Perspective. Mineralogical Magazine, 71, 389. https://doi.org/10.1180/minmag.2007.071.4.389

[11] Harlov, D.E., Wirth, R. and Hetherington, C.J. (2007) Replacement of Monazite by a Huttonite Component: Nature and Experiment. American Mineralogist, 92, 1652 1664. https://doi.org/10.2138/am.2007.2459

[12] Linthout, K. (2007) Tripartite Division of the System $2 \mathrm{REEPO}_{4}-\mathrm{CaTh}\left(\mathrm{PO}_{4}\right)_{2}-2 \mathrm{ThSiO}$, Discreditation of Brabantite, and Recognition of Cheralite as the Name for Members Dominated by CaTh $\left(\mathrm{PO}_{4}\right)_{2}$. The Canadian Mineralogist, 45, 503-508. https://doi.org/10.2113/gscanmin.45.3.503

[13] Breiter, K. and Förster, H.J. (2021) Compositional Variability of Monazite-Cheralite-Huttonite Solid Solutions, Xenotime, and Uraninite in Geochimically Distinct Granites with Special Emphasis to the Strongly Fractionated Peraluminous Li-F-PRich Podlesi Granite System (Erzgebirge/Krušné Hory Mts., Central Europe). Minerals, 11, Article No. 127. https://doi.org/10.3390/min11020127

[14] Spear, F.S. (2010) Monazite-Allanite Phase Relations in Metapelites. Chemical Geology, 279, 55-62. https://doi.org/10.1016/j.chemgeo.2010.10.004

[15] Zhu, X. and O’Nions, R.K. (1999) Zonation of Monazite in Metamorphic Rocks and Its Implications for High Temperature Thermochronology: A Case Study from the Lewisian Terrain. Earth and Planetary Science Letters, 171, 209-220. https://doi.org/10.1016/S0012-821X(99)00146-6

[16] Turlin, F., André-Mayer, A.S., Moukhsil, A., Vanderhaeghe, O., Gervais, F., Solgadi, F. and Pujol, M. (2017) Unusual LREE-Rich, Peraluminous, Monazite- or AllaniteBearing Pegmatitic Granite in the Central Grenville Province, Québec. Ore Geology Reviews, 89, 627-667. https://doi.org/10.1016/j.oregeorev.2017.04.019

[17] Zhang, J. and Edwards, C. (2013) A Review of Rare Earth Mineral Processing Technology. Mineral Processing CIM Journal, 4, 38-52.

[18] Jordens, A., Sheridan, R., Rowson, N. and Waters, K. (2014) Processing a Rare Earth Mineral Deposit Using Gravity and Magnetic Separation. Minerals Engineering, 62, 
9-18. https://doi.org/10.1016/j.mineng.2013.09.011

[19] Moustafa, M.I. and Abdelfattah, N.A. (2010) Physical and Chemical Beneficiation of the Egyptian Beach Monazite. Resource Geology, 60, 288-299. https://doi.org/10.1111/j.1751-3928.2010.00131.x

[20] Kim, K. and Jeong, S. (2019) Separation of Monazite from Placer Deposit by Magnetic Separation. Minerals, 9, Article No. 149. https://doi.org/10.3390/min9030149

[21] CN-ITIE (2019) Rapport de conciliation 2018. ITIE Senegal. Comité national de l'Initiative pour la Transparence dans les Industries Extractives du Sénégal (CN-ITIE). https:/itie.sn/rapport-itie-2019/ 